\title{
Spiritual Development through Elementary Physical Education Classes
}

\author{
Soni Nopembri \\ Faculty of Sports Science \\ Universitas Negeri Yogyakarta \\ Yogyakarta, Indonesia \\ soni_nopembri@uny.ac.id \\ Saryono \\ Faculty of Sports Science \\ Universitas Negeri Yogyakarta \\ Yogyakarta, Indonesia \\ saryono@uny.ac.id
}

\author{
Ahmad Rithaudin \\ Faculty of Sports Science \\ Universitas Negeri Yogyakarta \\ Yogyakarta, Indonesia \\ ahmad_rithaudin@uny.ac.id \\ Yoshio Sugiyama \\ Faculty of Human-environment Studies \\ Kyushu University \\ Fukuoka, Japan \\ sugiyama@ihs.kyushu-u.ac.jp
}

\begin{abstract}
-today, spiritual development through physical education is an unthinkable way to strengthen a harmonious society capable of contributing to the nation's character. Hence, this study aims to examine the effect of three types of physical education programs on children's religiosity and spirituality. For this study, 15 physical education teachers and 881 fourth to sixth-grade children participated in the study. The physical education programs were implemented over in the second semester of the 2015-2016 academic year. The data used was collected applying the 37 items of Religiosity and Spirituality Scale for Youth (RaSSY) (Hernandez, 2011) before and after of the program. Two- and one-way analyses of variance (ANOVA) and paired sample t-tests were used to compare the three groups. There was a significant interaction between the test and groups of mean religiosity and spirituality scores. The analysis also found a significant increase in the mean of these in the first and third groups. The planned, executed, and measured special physical education program in the first and third groups is an effective way to improve the religiosity and spirituality of the children.
\end{abstract}

\section{Keywords - Spirituality, Religiosity, Physical Education}

\section{INTRODUCTION}

In life, spirituality and religiosity are sensitive and important aspects, which require time and some strategic policies to involve the youths actively [1]. They both covey different meanings and yet they are interconnected [2]. From its definition, spirituality/religiosity refers to the appearance or presence of strength, power, energy, or the sense of God always with us [3]. Spirituality is "an essential aspect of religious practice" [4]. Hernandez emphasized that religiosity is the faith and praxis associated with religion or God while spirituality is the application of one's faith and praxis from contact and is independent of religion [5]. Specifically, religion is an organized system of faith, function, and practice, fixed in a religious tradition (invisible) or God's last right [6]. The relationship between spirituality and religion can be interpreted as follows: religion is the foundation of one's spirituality, and one's spirituality can grow without an underlying religion [7-9]. Spirituality is a basic life process, joy involvement, immolation, love and it connects people with themselves, others, and nature. [10]. Spirituality refers to personal experiences or seeks reality/transcendence that is not necessarily connected institutionally [6]. Spirituality focuses on sense, luxury, and reconciliation, which helps individuals to change their condition and build a new self-concept [9]. In relation to this study, the spirituality and religiosity of children can improve by implementing an effective educational curriculum system.

Spirituality is based on clear indicators and specific outcomes which is a vital part of the curriculum, especially in reference to the health and well-being that is achievable through deep relationships with others, nature, and past experiences [8]. Spirituality, also refers to a learning dimension of physical education and health, which has been incorporated in a holistic-oriented curricula and the pedagogy is clearly open to integrate the cultural orientation of motion and balance, and it enhances the spiritual awareness of students [10]. Furthermore, Health and physical education provides many opportunities for children to experience spirituality through through the implementation of regular physical activities in weekly lessons [13]. Furthermore, Lodewyk, Lu, and Kentel stated that students' spiritual development can be promoted through participation in physical activities, games, traditional culture, and music to help be more relaxed, creative, motivated, able to interact with each other [10]. Consistent with that opinion, Jirásek focuses on using the concept of spiritual health in physical education by essentially characterising the existence, relationships, reality and purpose of life, and transfer [2]. There are some practical ways to implement spirituality in health and physical education such as breaking down the explanation of different movements in a physical activity, describing acts of heroism in the world of sports, talking about the benefits of a sport, motivating students to do kind acts during physical activities, and discussing issues that will touch the heart of students to do good to others [8]. Hence, this study aims to examine the effects of the three types of physical education (PE) discussed in this study on the religiosity and spirituality of children. From our findings, we hypothesized that the administration of $\mathrm{PE}$ and sports program to the children relatively increases their religiosity and spirituality. 


\section{METHOD}

\section{A. Participants}

Fifteen elementary schools were randomly organized into the first, second, and third groups. The schools were randomly selected in the intervention program [12]. Based on that, $15 \mathrm{PE}$ teachers and 881 children (480 girls and 401 boys) from the fourth to sixth-grade elementary schools were selected for the study. Specifically, with respect to the characteristic age of the children, their ages ranged from 8 to 15 years $($ Mean $=10.6, \mathrm{SD}=1.12)$. There were 323 children consisting of 126 females and 197 males in the first group (ages: Mean $=10.9, \mathrm{SD}=1.19$ ). The second group had 187 children; 91 females and 96 males (ages: Mean $=10.5, \mathrm{SD}=$ 1.03). The third group had 371 children; 155 females and 175 males (ages: Mean $=10.4, \mathrm{SD}=1.05)$.

\section{B. Procedure}

The study implemented an experimental design on the PE and sports programs with three different conditions. The schools that participated were selected randomly into three groups, and the Religiosity and Spirituality Scale for Youth (RaSSY) was performed on all the children before the programs commenced. The teachers of the three groups were actively involved in focus-group discussions about the success of their programs. All teachers and students across all groups implemented their programs over one semester in the 2016-2017 school year, and by the program end, the measurement on the religiosity and spirituality of children was retaken a using the same instrument.

\section{Data Collection}

The RaSSY developed by Hernandez [5] was used to measure the children's religiosity and spirituality. The 37 items in this scale comprise two factors: 1) faith-based coping (22 items) - the use of religious beliefs, knowledge, and prayers to get comfort, strength, relief, or guidance - and 2) religious, social support/activities (15 items) - religious, social support and participation in other religious activities. Items were rated on a 4-point scale, ranging from $0=$ "never" to 3 = "almost always," indicating the degree to which respondents agreed with each item. The researcher together with a professional translator translated the original scale from English to simple Indonesian. Then, the scale was examined for its validity and reliability. The results of exploratory and confirmatory factor analysis and internal consistency indicate that the scale was quite suitable for our research.

\section{Data Analysis}

The Two-way ANOVA was used to assess the effect of the interaction and the major differences between the intervention and control groups before and after the programs. The paired sample t-tests were also carried out to evaluate the differences within groups. In the study, all analysis was carried out with the SPSS Version 22.0 software for Windows, and the statistical significance was set at $\mathrm{p}<0.05$.

\section{RESULTS}

From the results, there was a statistically significant effect between the interaction of the mean scores of religiosity and spirituality between the test $(\mathrm{F}(2,878)=4.177, \mathrm{p}=0.016)$. In contrast, these were not significantly different $(F(2,878)=$ $0.152, \mathrm{p}=0.859$ ) when the pre and post-test groups were combined. Figure 1 represents a significant difference in the mean change of religiosity and spirituality from pre- to postintervention among the groups. Post hoc analysis of Least Significant Difference (LSD) also showed statistically significant differences in mean scores of religiosity and spirituality between the intervention and first control group ( $p$ $=0.006)$ and also between the intervention and the second group $(\mathrm{p}=0.041)$, However, it did not show up between the first and second control groups $(\mathrm{p}=0.287)$.

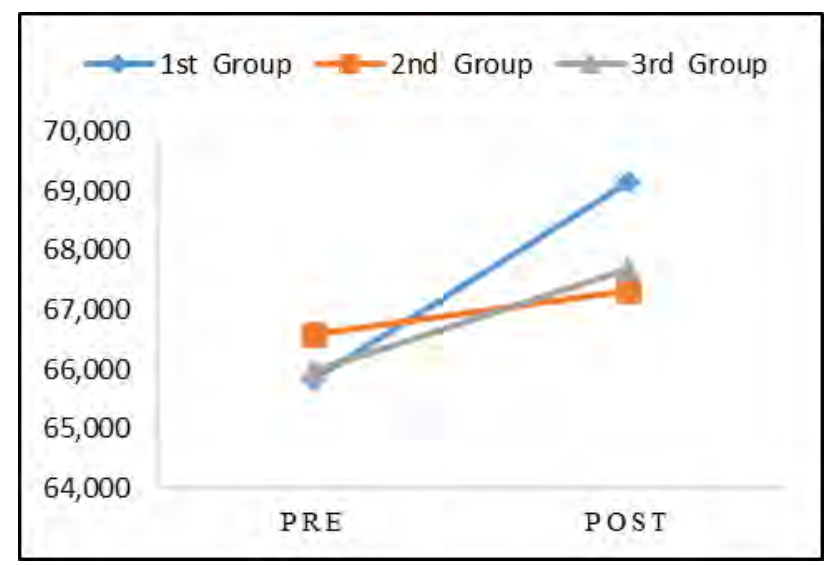

Fig. 1. Interaction of the mean of religiosity and spirituality between groups.

Furthermore, a statistically significant enhancement was highlighted in the religiosity and spirituality of the intervention group after the psychosocial and traditionalbased PE and sports program $(\mathrm{t}(322)=-7.245, \mathrm{p}=0.000)$. Similarly, the second control group $(\mathrm{t}(370)=-2.741, \mathrm{p}=$ 0.006 ) also showed a statistically significant increase of scores after their program. In contrast, the first control group $(\mathrm{t}(186)=-1.104, \mathrm{p}=0.271)$ did not significantly increase the scores. Thus, a conclusion can be drawn that the intervention and control groups displayed an increased religiosity and spirituality because of the respective programs they underwent. The enhancement of these skills in all groups is summarized below in Table I.

TABLE I. THE PAIRED SAMPLE-T TEST RESULTS

\begin{tabular}{|c|c|c|c|c|c|c|}
\hline \multirow{2}{*}{ Group } & \multicolumn{2}{|c|}{ Mean } & \multicolumn{2}{|c|}{ SD } & \multirow{2}{*}{ df } & t \\
\cline { 2 - 5 } & Pre & Post & Pre & Post & & \\
\hline First & 65.83 & 69.14 & 18.72 & 17.41 & & $-7.245^{* *}$ \\
\hline Second & 66.58 & 67.32 & 17.13 & 17.12 & \multirow{2}{*}{2.878} & -1.104 \\
\hline Third & 65.96 & 67.67 & 16.17 & 16.59 & & $-2.741^{* *}$ \\
\cline { 3 - 5 } & \multicolumn{5}{|c|}{ a. Note: **p $<0.05$ in two-tailed test, SD=Standard Deviation }
\end{tabular}

\section{DISCUSSION}

In this study, it was found that the special PE and sports programs based on psychological and traditional grounds in the first group enhanced the children's religiosity and spirituality. The results are supported by the study of Lodewyk, Lu, and Kentel [10], which found that religious and spiritual, values, such as awareness, caring, serenity, and 
tolerance were activated during the physical education. Likewise, the health and PE lessons influence the spiritual development with greater potentials, which is related to daily school and community activities [13]. This study's results are also consistent with those of Hilty [14], who found that running had a spiritual and religious aspect because its repetitive motion and mind-clearing influence helped individuals find meaning and purpose in life, similar to the religious practitioners. Children's interest in health and PE forms their attitude towards physical activity and spirituality [11]. The children's spirituality was firmly associated with happiness; therefore, they should be happier if they become more spiritual [14]. In conclusion, the outcomes of physical education, including its cognitive, affective, and psychomotor aspects, should support children's spirituality [15]. Likewise, spirituality/religiosity and sports have connections with various aspects of human life. Sport can develop a religious attitude based on mutual respect and can overcome recognized differences [2]. Parry reported relationships between many aspects of sports and spirituality, such as health and well-being, ethical development, and the spirit of the game [16]. The physical aspects of young people, such as strength, endurance, dexterity, precision, and the ability to analyse situations are the foci of development in national sports [17]. Religious values, practices, and rituals often appear in the context of sports [2, 18]. Amara [19] reported a relationship between sports and spirituality and religiosity in programs involving religious minorities as national sports event hosts.

During the PE and sports program of first group, the researchers included a break of 10 minutes for relaxation at the end of the each lesson. This addition was based on the idea children's spirituality can be possibly enhanced through Eastern forms of movement, such as yoga, meditation, and relaxation exercises during the cool-down phase of a lesson. [10]. Sports and meditation focused on the mind, body, and attention are essential aspects of a religious or spiritual life [4]. Spirituality is the critical fundamental dimension of education, health, and well-being and referred to as spiritual health [8]. The implemented PE and sports program also emphasizes praying at the beginning and the end of lessons to promote children's serenity, commitment, bonding with friends, control of their emotions, and achievement [20-21]. With consistency in the implementation of prayers, a lot of professional sports men and women have developed praying habits in their games or physical activities [3, 18] to ask for success for themselves and team, and so, to express gratitude for the results in the end [2].

Similarly, the results from the third group implemented the former curriculum of the PE and sports program. These results were unexpected because the researcher did not emphasize on religiosity or spirituality during their program. Many possible reasons could have warranted this outcome, for example, the Islamic religious-based schools might have affected the increase of children's religiosity and spirituality. A relationship between spirituality/religiosity, health, and wellbeing has been reported in several research studies. Hernandez [5] found that spirituality/religiosity affects the wellbeing and health improvement of adults. Hurych [7] showed that spirituality is the motivating force that drives competition or health improvement. This possibility is likened to the fact that in Islam, all of the human aspects are important [22]. Moreover, for Muslims, participation in sports events is related to their existence and faith $[19,23]$. According to Islam, a good Muslim enjoys good health and fitness [23]. An association between spirituality and overall health was reported in the research literature [24].

\section{CONCLUSION}

From the studies, the PE and sports programs facilitated the development of the children's behaviors and attitudes related to their spiritual and religious beliefs, which led to an increased level of religiosity and spirituality. Notably, Religion-based schools made large contributions to the enhancement of the children's spirituality and religiosity. These schools regularly perform a variety of religious traditions and rituals daily in their school, including in the $\mathrm{PE}$ and sports lessons. The researcher identified some study limitations, including the children's religious backgrounds, differences in the teachers' abilities to implement the program, school equipment, and infrastructural deficiencies, and school policy differences in the PE and sports programs. A comprehensive and in-depth investigation based on the spirituality and religiosity of children is needed for future studies. The relationship among physical, psychosocial, spiritual, and religious aspects should also be investigated.

\section{ACKNOWLEDGMENT}

JSPS KAKENHI Grant Number JP16K12980 and Fundamental Research Grant from the Ministry of Research, Technology and Higher Education of the Republic of Indonesia supported this wok.

\section{REFERENCES}

[1] M. Bullock, L. Nadeau, J. Renaud, "Spirituality and religion in youth suicide attempters' trajectories of mental health service utilization: the year before a suicide attempt", Journal of the Canadian Academy of Child and Adolescent Psychiatry, 2012, vol. 21, no. 3, pp.186-193.

[2] I. Jirásek, "Religion, Spirituality, and Sport: From Religio Athletae Toward Spiritus Athletae", Quest, 2015, vol. 67, no. 3, pp. 290-299.

[3] K. M. Dillon, J. L. Tait, "Spirituality and being in the zone in team sports: A relationship?", Journal of Sport Behavior, 2000, vol. 23, no. 2, pp. 91-100.

[4] B. Hilty, More than the physical: running as a spiritual experience. Undergraduate Honors Theses, paper 1231, University of Colorado: Boulder, 2016.

[5] B. C. Hernandez, The religiosity and spirituality scale for youth: development and initial validation, Doctoral Dissertation. The Department of Psychology, the Graduate Faculty of the Louisiana State University and Agricultural and Mechanical College: Louisiana, 2011.

[6] R. E. Dew, S. S. Daniel, D. B. Goldston, W. V. McCall, M. Kuchibhatla, C. Schleifer, M. F. Triplett, H. G. Koenig, "A prospective study of religion/spirituality and depressive symptoms among adolescent psychiatric patients", Journal of Affective Disorders, 2010, vol. 120, no. 1-3, pp. 149-157.

[7] E. Hurych, "The perception of spirituality in different selected areas of movement activity", The $3^{\text {rd }}$ International Society for the Social Sciences of Sport Conference, Olomouc: Czech Republic, pp. 8-15, 2011.

[8] A. Anderson, "Spirituality as an integral part of education for health", Physical \& Health Education Journal, 2007, vol. 73, no. 1, pp. 14.

[9] N. Parsian, T. Dunning, "Developing and validating a questionnaire to measure spirituality: a psychometric process", Global Journal of Health Science, 2009, vol. 1, no. 1, pp. 1-11. 
[10] K. Lodewyk, C. Lu, J. Kentel, "Enacting the spiritual dimension in physical education", Physical Educator, 2009, vol. 66, no. 4, pp. 170179.

[11] T. Lynch, "Exploring religious education and health and physical education key learning area connections in primary schools", The International Journal of Humanities Education, 2013, vol. 10, no. 2, pp. 11-23.

[12] K. Ronan, D. Johnston, "Behaviourally-based interventions for children following volcanic eruptions: an evaluation of effectiveness", Disaster Prevention and Management: An International Journal, 1999, vol. 8, no. 3, pp. 169-176.

[13] T. Lynch, "Investigating Children's Spiritual Experiences through the Health and Physical Education (HPE) Learning Area in Australian Schools", Journal of Religion and Health, 2013, vol. 54, no. 1, pp. 202220.

[14] M. Holder, B. Coleman, J. Wallace, "Spirituality, Religiousness, and Happiness in Children Aged 8-12 Years", Journal of Happiness Studies, 2008, vol. 11, no. 2, pp. 131-150.

[15] National Association for Sport and Physical Education (NASPE), Moving into the Future: National Standards for Physical Education. Reston, VA: McGraw-Hill, 2005.

[16] J. Parry, S. Robinson, N. Watson, M. Nesti, Sport and spirituality. An introduction. London, UK: Routledge, 2007.
[17] U. Marchibayeva, "Spiritual and practical origins of traditional sport events", International Journal of Physical Education, Sports, and Health, 2016, vol. 3, no. 3, pp. 364-366.

[18] R. S. Obare, Can sport exist without religion? Sheffield, England: Sheffield University Press, 2000.

[19] M. Amara, "Sport, Islam, and Muslims in Europe: in between or on the Margin?", Religions, 2013, vol. 4, no. 4, pp. 644-656.

[20] J. J. Coakley, Sport in society (8th Ed.). Boston: Irwin McGraw-Hill, 2003.

[21] N. J. Watson, D. R. Czech, "The Use of Prayer in Sport: Implications for Sport Psychology Consulting", The online Journal of Sport Pyschology, 2005, vol. 7, no. 4, pp. 26-35.

[22] H. Khanifar, S. M. Moghimi, S. A. B. Memar, G. Jandaghi, "Ethical considerations of physical education in an Islamic valued system", Online Journal of Health Ethics, 2008, vol. 1, no. 1, pp. 1-13.

[23] I. K. Wabuyabo, E. K. Wamukoya, H. M. Bulinda, "Influence of Islam on gender participation in sports among Muslim students in Kenyan universities", Journal of Physical Education and Sport Management, 2015 , vol. 6 , no. 9 , pp. 82-89.

[24] B. E. Udermann, "The effect of spirituality on health and healing: a critical review for athletic trainers', Journal of Athletic Training, 2000, vol. 35, no. 2, pp. 194-197. 